Turturean, M. (2022). Teaching and learning in higher education during Covid 19 pandemic - a comparative study. Problems of Education in the Fourth Industrial Revolution Era. European Scientific e-Journal, 1 (16), 7-20. Ostrava: Tuculart Edition.

Turturean, M. (2022). Teaching and learning in higher education during Covid 19 pandemic - a comparative study. Problems of Education in the Fourth Industrial Revolution Era. European Scientific e-Journal, 1 (16), 7-20. Ostrava: Tuculart Edition.

$$
\text { DOI: } 10.47451 / \text { ped2022-01-03 }
$$

The paper will be published in Crossref, ICI Copernicus, Academic Resource Index ResearchBib, J-Gate, ISI International Scientific Indexing, Zenodo, OpenAIRE, BASE, LORY, LUASA, ADL, eLibrary, and WebArchive databases.

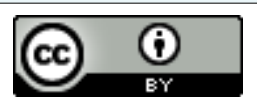

Monica Turturean, $\mathrm{PhD}$ in Education, Assistant Professor, Teacher Training Department Faculty of Sciences of Education, Stefan cel Mare University of Suceava. Iasi, Romania.

ORCID: 0000-0003-4030-7974. Semantic Scholar: 75125394.

\title{
Teaching and learning in higher education during Covid 19 pandemic - a comparative
} study

Abstract: Since March 2020, when lock-down was imposed in Romania, education has been hit very hard and all educational institutions have suffered major, irrecoverable losses. According to the United Nations Educational, Scientific and Cultural Organisation (UNESCO), over 800 million learners from around the world have been affected, 1 in 5 learners cannot attend school, 1 in 4 cannot attend higher education classes, and over 102 countries have ordered nationwide school closures while 11 have implemented localized school closure. Grant Kasowanjete, GCE Global Coordinator says: "Governments and civil society concerted efforts that mobilize resources, and expertise to address the impact of COVID-19 on education is urgently required. This process should include developing long term strategies to address the needs of education in emergencies". Bania and Banerjee (2020) show that universities from all over the world have responded to COVID-19 differently: some have continued face-to-face teaching with social distancing (e.g., the University of Queensland, Australia), while others have deferred all academic activities (e.g., the Oxford University, UK). In Romania, the situation was dramatic during the lock-down period, all universities had to switch to online teaching, which took them unprepared, both teachers and students. The study purpose is to identify the perception / opinion of university teachers from Alexandru Ioan Cuza University of Iasi (Al.I. Cuza) and from Gheorghe Asachi Technical university of Iasi (Gh, Asachi) regarding the effects of pandemic COVID 19 for their teaching and learning. The Statistical Package for Social Science Program (SPSS) was used to summarize and run correlation on data obtained from the survey. Therefore, we conducted a comparative study between 2 universities in the area of Moldova, to see the opinion of teachers related to online teaching at that time and its negative effects.

Keywords: pandemic, COVID-19 lockdown, online education, electronical devices, university teachers.

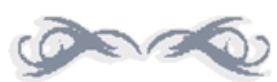

Monica Turturean, Doctor in Stiintele Educatiei, Asistent universitar doctor, Teacher Training Department Faculty of Sciences of Education, Stefan cel Mare University of Suceava. Iasi, Romania. ORCID: 0000-0003-4030-7974. Semantic Scholar: 75125394.

\section{Predarea şi învăţarea la nivel universitar în timpul carantinei datorate infecției cu COVID-19}


Rezumat: Din martie 2020, când a fost impusă carantina în România, şi nu numai, educația a fost lovită foarte puternic şi toate instituțiile de învăţământ au suferit pierderi majore, irecuperabile. Potrivit Organizației Națiunilor Unite pentru Educație, Ştiință şi Cultură (UNESCO), peste 800 de milioane de elevi din întreaga lume au fost afectați, 1 din 5 elevi nu au putut merge la şcoală, 1 din 4 nu au putut merge la cursurile din universități şi peste 102 țări au impus închiderea şcolilor, în timp ce 11 au implementat închiderea locală a şcolilor. Grant Kasowanjete, coordonatorul global al GCE, a declarat: „Guvernele şi societatea civilă trebuie să depusă eforturi foarte mari care mobilizează resurse şi expertiză pentru a aborda impactul COVID-19 asupra educației. Acest proces ar trebui să includă dezvoltarea de strategii pe termen lung pentru a răspunde nevoilor educației în situații de urgență”. Bania şi Banerjee (2020) arată că universitățile din întreaga lume au răspuns diferit la COVID-19: unele au continuat predarea faţă în faţă cu distanțare socială (de exemplu, Universitatea din Queensland, Australia), în timp ce altele au amânat toate activități academice (de exemplu, Universitatea Oxford, Marea Britanie). În România, situația a fost dramatică în perioada de izolare, toate universitățile au fost nevoite să treacă la predarea online, prinzându-i "descoperiți", atât pe profesori, cât şi pe studenți. Prin urmare, am realizat un studiu comparativ între 2 universități din zona Moldovei, pentru a surprinde opinia cadrelor didactice universitare legate de predarea online la acea vreme şi efectele negative ale acesteia.

Cuvinte cheie: pandemie, carantină COVID-19, educație online, dispozitive electronice, profesori universitari.

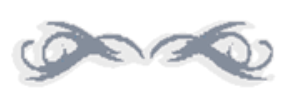

\section{Introduction}

In the last two years, education has suffered major losses, both at pre-university and academic level, both nationally and internationally. Online teaching has proved ineffective, both for pupils and for students, teachers. The efforts were very great not to block the school year, so that the pupils and students could follow their educational path. However, the disadvantages of online teaching have been huge, starting with the cognitive and continuing with the socioemotional, physiological, etc. Therefore, it is important to capture the opinion of teachers about online teaching, about how they have managed to adapt to something new, to something they have not done before, to know how comfortable they felt, how "masters" of the situation and, thus, to know what we can do next, what strategies to adopt so that the pupils / students do not end up in this situation and the teachers can be trained so that they can face the challenges on which involves online teaching, which means both a specialized training (methods, teaching techniques and content adapted to online learning), and a psychological training to be able to help pupils / students who face emotional, social problems due lack of interaction with other colleagues, friends, teachers.

The study subject is to capture the negative effects of quarantine with COVID-19, which involved online learning, on university professors, on students' school performance, on their socio-emotional development.

The study purpose is to identify the perception / opinion of university teachers from Alexandru Ioan Cuza University of Iasi (Al.I. Cuza) and from Gheorghe Asachi Technical university of Iasi (Gh, Asachi) regarding the effects of pandemic COVID-19 for their teaching and learning.

Based on the study purpose, the following tasks are: 
- identify the university teachers' opinion regarding pandemic COVID 19 and its effects

- see if there are differences between teachers from Alexandru Ioan Cuza University of Iasi

(Al. I. Cuza) and from Gheorghe Asachi Technical university of Iasi (Gh, Asachi) related to forced online education

- $\quad$ find out if this pandemic has affected them or not.

The Statistical Package for Social Science Program (SPSS) was used to summarize and run correlation on data obtained from the survey. Frequency distribution used to mention demographics of teachers. Correlation technique was utilized to discuss relationship between teachers from two universities and their opinion regarding online teaching.

In the study course, the author used theoretical (Bania, J., \& Banerjee, I., 2020; Gorey, Jon, 2020; Philani, 2020) and practical (Alliance for Children Protection, 2021; Banca Mondială, 2020) bibliographic resources of a to form a clearer picture of the impact of this pandemic on education.

\section{Covid-19 lockdown and online teaching}

With the quarantine imposed on March 10, 2020, in Romania, all universities "closed their doors", being forced to switch to online teaching. This solution was taken so as not to freeze the academic year and so that students do not repeat the year of study.

Both teachers and students had to face great challenges, such as: resistance to change for both teachers and students related to the way they work; the absence of electronic devices and special software that favor online teaching and learning, etc.

Everyone was scared of this overnight change and no one was willing to invest more because there was a severe fear of COVID 19 infection, which put them all in a deadlock, unproductive for anyone. Teachers did not know how to teach online because they had not been taught how to do it, students were not willing to learn because it was a completely different way than the one, they knew, etc.

For teachers, the shift to online education has meant rethinking lesson plans to fit a very different format. "You sort of have to redo all of the curriculum so you can teach it online, because a lot of it was dependent on you being there and leading the students through certain things," says Tina Morris, science teacher and sustainability director at The Pike School in Massachusetts (Jon Gorey, 2020).

Pandemic COVID-19 had a negative role for children, for education, for their mental and emotional health. "One year into the COVID-19 pandemic, progress has gone backward across virtually every key measure of childhood," said Henrietta Fore, UNICEF Executive Director. "The number of children who are hungry, isolated, abused, anxious, living in poverty and forced into marriage has increased. At the same time, their access to education, socialization and essential services including health, nutrition and protection has decreased. The signs that children will bear the scars of the pandemic for years to come are unmistakable." (UNICEF says as pandemic declaration bits one-year mark: Spokespeople available for interview, 2021)

GCE (Global Campaign for Education) calls on the national governments, and donors:

- prioritize education in the first phase of all emergency responses with immediate effect, and to Include education in their COVID-19 response policies. 
- dedicate appropriate resources, financial and technical, to ensure the right to free, quality public education for all is maintained during the COVID-19 crisis.

- increase funding and support to education in crises to a minimum of $4.2 \%$ of emergency assistance in line with its needs.

- minimize the pressure on teachers, schools and school systems that remain open or volunteer to offer extra support. (Philani, 2020)

Thus, what can be done in order to help everyone, both teachers and students?

Maybe we will find solutions in the near future, solutions that involve the creation of professional networks for teachers, networks that contain courses, bibliographic successes, models of good practices to use online learning as an alternative form of education because education requires flexibility, adaptation the new, the unknown. Even WorldBank propose some policy responses to achieve this, which can be summarized in three overlapping phases:

- Coping

- Managing Continuity

- Improving and Accelerating (WorldBank, 2020).

\section{Comparative study on teachers' opinion on the effects of the COVID-19 pandemic}

\section{Purpose and objectives}

The purpose of this study is to identify the perception / opinion of university teachers from Alexandru Ioan Cuza University of Iasi (Al. I. Cuza) and from Gheorghe Asachi Technical university of Iasi (Gh, Asachi) regarding the effects of pandemic COVID-19 for their teaching and learning.

The study objectives are:

- identify the university teachers' opinion regarding pandemic COVID-19 and its effects

- $\quad$ see if there are differences between teachers from Alexandru Ioan Cuza University of Iasi (Al. I. Cuza) and from Gheorghe Asachi Technical university of Iasi (Gh, Asachi) related to forced online education

- find out if this pandemic has affected them or not

Hypothesis:

1. The teachers from Al. I. Cuza University were more affected by the pandemic COVID-19 than teacher from Gh. Asachi University.

2. The effects of this deprivation are felt even by the students which will see the differences before and during pandemic COVID-19.

\section{Participants}

The sampling survey was applied to a non-probability sampling group. The students were selected randomly from the university site' emails.

- $\quad$ university teachers from Alexandru Ioan Cuza University of Iasi: 75;

- $\quad$ university teachers from Gheorghe Asachi University of Iasi: 75.

\section{Instrument}

We used a sampling survey with predefined answers that allowed participants to complete it more easily and not feel pressured because they do not know how to answer various questions.

\section{Procedure}


The statistical method used is identifying the perception / opinion of of university teachers from Alexandru Ioan Cuza University of Iasi (Al. I. Cuza) and from Gheorghe Asachi Technical university of Iasi (Gh, Asachi) regarding the effects of pandemic COVID-19 for their teaching and learning.

The study is based on the data yielded following a sampling survey which investigates the opinion of of university teachers from Alexandru Ioan Cuza University of Iasi (Al. I. Cuza) and from Gheorghe Asachi Technical university of Iasi (Gh, Asachi) regarding the effects of pandemic COVID-19 for their teaching and learning.

The investigative technique used was the auto-questionnaire survey consisting in 9 questions administered individually.

\section{Data analysis}

The Statistical Package for Social Science Program (SPSS) was used to summarize and run correlation on data obtained from the survey. Frequency distribution used to mention demographics of teachers. Correlation technique was utilized to discuss relationship between teachers from two universities and their opinion regarding online teaching.

The favored surveying technique was the individual filling in of the questionnaire in a group. (Rotariu T., \& Ilut P, 1997:54). This surveying technique was chosen because it is the easiest and less expensive.

Thus, we can conclude that new studies are needed, more complexes, on bigger samples of subjects (not only teachers, but students too), studies that require pretesting of the questionnaire, forming interdisciplinary teams to study the subject from several perspectives in order to have a complete picture of the phenomenon, but also to find effective solutions so that the situation faced by these teachers and students will not be repeated in the near future.

\section{Study Results}

According to the data of figure 1, 47\% of teachers from Al. I Cuza University used an opensource platform during the lockdown period, but 39\% of teachers from Gh. Asachi University have used online teaching. So, there are significant differences between teachers from Al. I Cuza University and teachers from Gh. Asachi regarding the way of teaching.

According to the data of figure 2, it can be seen that $47 \%$ of teachers from Al. I. Cuza University of Iasi used a Moodle Platform, a big percentage comparing with $37 \%$ of teachers from Gh. Asachi University of Iasi which use a Mooodle platform too. 24\% of teachers from Gh. Asachi University of Iasi used Teems platform and $20 \%$ of teachers from Al. I. Cuza University of Iasi used the same platform / app.

According to the data of figure 3, 47\% of teachers from Al. I. Cuza University of Iasi and $37 \%$ of teachers from Gh. Asachi University of Iasi consider that it was not difficult to teach online because they used those apps before. 11\% of teachers from Al. I. Cuza University of Iasi and $4 \%$ of teachers from Gh. Asachi University of Iasi didn't teach online.

It is interesting to see that $43 \%$ of teachers from Al. I. Cuza University of Iasi and 39\% of teachers from Gh. Asachi University of Iasi declare that although they tried, they didn't really help their students. 32\% of teachers from Al. I. Cuza University of Iasi and $41 \%$ of teachers from Gh. Asachi University of Iasi consider that they didn't help students very much (Figure 4). 
In figure 5 , it can be seen that 33\% of teachers from Al. I. Cuza University of Iasi and 31\% of teachers from Gh. Asachi University of Iasi faced with the fact that their students didn't have the electronically devices in order to participate at online courses; instead, $39 \%$ of teachers from Gh. Asachi University declare that their students didn't have internet connection.

The answers on the Question 6 (Figure o) were different: 47\% of Al. I Cuza University consider that during the lockdown, their students felt insecurity, fear, uncertainty, instead $47 \%$ of Gh. Asachi University consider that the negative impact of the lockdown was related with the fact that their students had low school performance and only $24 \%$ of teachers from Al. I. Cuza University declare low performance.

One of the solutions approved by teachers from both universities (40\% of teachers from Al. I. Cuza University and 35\% of teachers from Gh. Asachi University) is individual work with students who cannot adapt to online teaching. 33\% of teachers from Gh. Asachi University consider that another solution is to offer laptops or tablets to students and $31 \%$ of teachers from Al. I Cuza Universisity is to create courses for students to learn how to use electronic apps (Figure 7 .

Regarding the Question 8 (Figure 8) "What should be done to overcome the emotional problems?", $56 \%$ of teachers from Gh. Asachi University and 37\% of teachers from Al. I. Cuza University consider that students should learn more to overcome their emotional problems. It is interesting to see that many teachers considers that there is a direct connection between emotional problems and lower performance.

The answers on this question are surprising: 40\% of Gh. Asachi University is not agreed with registering and posting their courses on an online platform and 39\% of teachers from $\mathrm{Al}$. I. Cuza University are willing to do this, but they don't think that this is a good idea (Figure 9).

\section{Validation of the hypothesis}

The first hypothesis „The teachers from Al. I. Cuza University were more affected by the pandemic COVID-19 than teacher from Gh. Asachi University" was invalidated by the answers offered by teachers on Question 3 (43\% of teachers from Al. I. Cuza University of Iasi and 20\% of teachers from Gh. Asachi University of Iasi consider that it was extremelly difficult because I didn't know how to teach online, so, their answers were quite similar).

The second hypothesis "The effects of this deprivation are felt even by the students which will see the differences before and during pandemic COVID 19" was validated by the answers offered by the teachers from both universities ( $47 \%$ of Al. I Cuza University consider that during the lockdown, their students felt insecurity, fear, uncertainty and $47 \%$ of Gh. Asachi University consider that the negative impact of the lockdown was related with the fact that their students had low school performance).

\section{The main limit of the study}

Sample consists only of high school students from teachers from Al. I Cuza University of Iasi and teachers from Gh. Asachi University of Iasi Cso these results cannot be extended to the entire population of Romanian population. There will be no pre-testing the subjects, which means that we cannot obtain the accuracy of the results.

There is no control group. 


\section{Discussions}

As expected, we find that both teachers and students suffered during this difficult period. Both parties were unprepared to move from the physical to the virtual environment, which created various problems: inability to adapt to online teaching, emotional problems, a bad communication, poor performances, etc.

Teachers and students will never be the same after this pandemic period, both of them must adapt to this situation which may last for a while. But the universities must be the promotor of social inclusion, of equity, which means collaborations between all social actors to bring students into university learning environments that could not otherwise be there.

It will not be easy to overcome this period of stagnation or regression, without opting for an inclusive education, able to respond positively to the training needs of all student and to help them to solve their emotional and social problems.

\section{Conclusion}

The impact of online learning due to the lockdown is a topic that interests the whole academic world because it is a starting point for the development of educational policies that would counteract the negative effects of this period, but also the development of coping strategies so that, both teachers and students should be prepared to face such educational challenges.

We can conclude that the results obtained from the statistical processing of the answers offered by the 150 university teachers are not relevant for the sample of university teachers in Romania (due to the very small number of study participants), but may be an important starting point. allowing the collection of new statistical data, new information on the subject, but also to help teachers and students from entire world to have a complex image of this phenomenon.

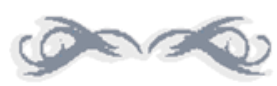

\section{References:}

Across virtually every key measure of childhood, progress has gone backward, UNICEF says as pandemic declaration hits one-year mark: Spokespeople available for interview (2021, March 10). Retrieved January 5, 2021, from https://www.unicef.org/press-releases/acrossvirtually-every-key-measure-childhood-progress-has-gone-backward-unicef-says

Bania, J., \& Banerjee, I. (2020). Impact of Covid-19 on Higher Education: A Critical Review. Global University Network for Innovation. Retrieved January 10, 2021, from http://www.guninetwork.org/report/impact-covid-19-pandemic-higher-educationcritical-review

Bettelheim, B. (1976). The uses of enchantment: the meaning and importance of fairy tales. NewYork: Knoph.

Crearea unor sisteme de educație reziliente în contextul pandemiei de COVID-19: Considerente pentru factorii de decizie de la nivel național, local şi de unitate şcolară (2020). Geneva: Biroul Regional UNICEF pentru Europa şi Asia Centrală. Retrieved January 15, 2022 from https://www.unicef.org/romania/media/2836/file/Crearea $\% 20$ unor $\% 20$ sisteme $\% 20 \mathrm{de} \%$ 
20educa $\%$ C5 $\%$ A 3 ie $\% 20$ reziliente $\% 20 \%$ C $3 \%$ AEn $\% 20$ contextul $\% 20$ pandemiei $\% 20$ de $\% 20$

COVID-19.pdf (in Romanian)

Gorey, Jon (2020, September 19). Teaching in a Pandemic: How Educators Are Handling the Sudden Shift to Distance Learning. Retrieved January 10, 2021, from https://earthwatch.org/stories/teaching-pandemic-how-educators-are-handling-suddenshift-distance-learning

În perioada pandemiei de COVID-19. Copiii şi îngrijirea alternativă (2021). Elaborarea acestei Note tehnice a fost coordonată de către Care Network. Alianța pentru Protecția Copilului In Acţiuni Umanitare şi UNICEF. Retrieved January 15, 2022, from https://resourcecentre.savethechildren.net/pdf/covid-19 tn romanian.pdf/ (in Romanian)

Philani (2020, March 18). CoronaVirus: Don't Let Our Children Down! Retrieved January 7, 2021, from https://campaignforeducation.org/en/2020/03/18/coronavirus-dont-let-ourchildren-down/

Rotariu, T., \& Ilut,, P. (1997). Ancheta sociologica si sondajul de opinie. Teorie si practica. Iasi: Polirom. (in Romanian)

The COVID-19 Pandemic: Shocks to Education and Policy Responses (2020). Banca Mondială. Mai 2020. Washington. Grupul Băncii Mondiale.

UNICEF, OMS, IFRC (2020) Interim Guidance for COVID-19 Prevention and Control in Schools. Retrieved December 15, 2021, from https://www.unicef.org/media/66216/file/Key $\% 20$ Messages $\% 20$ and $\% 20$ Actions $\% 20$ for $\% 20$ COVID-

19\%20Prevention $\% 20$ and $\% 20$ Control $\% 20$ in $\% 20$ Schools March $\% 202020$.pdf 


\section{Appendix}

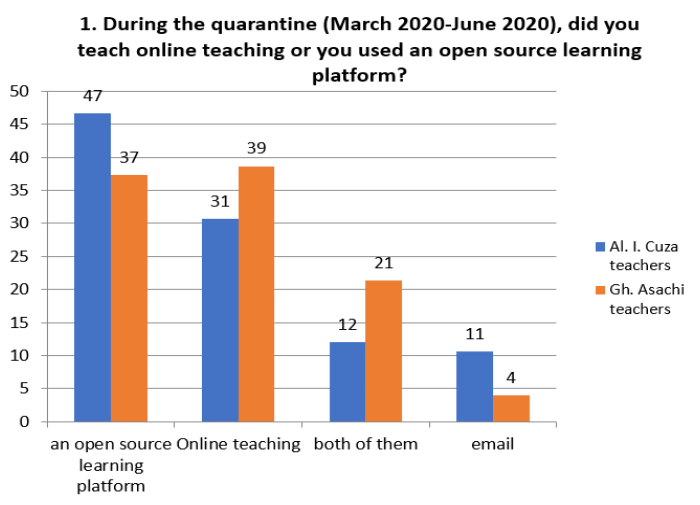

Figure 1. The structure of answers at question Q1

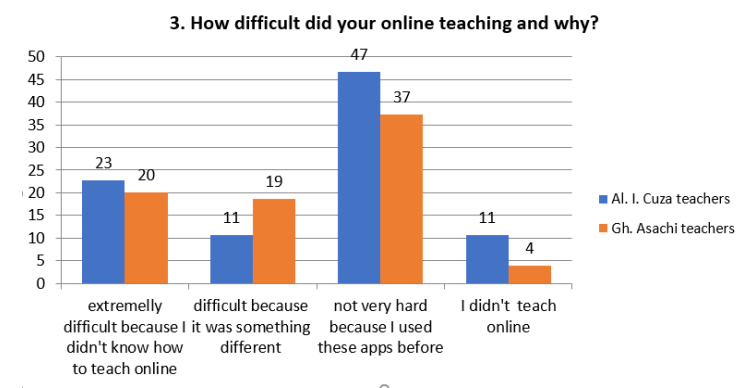

Figure 4. The structure of answers at question Q3
2. Which apps or platform did you used in that period?

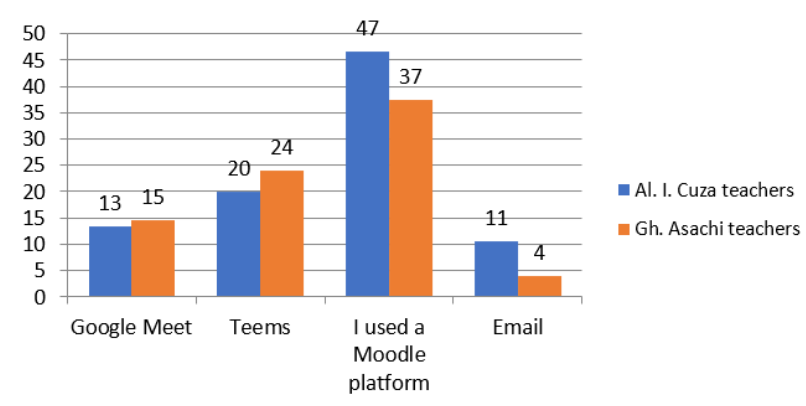

Figure 2. The structure of answers at question Q2

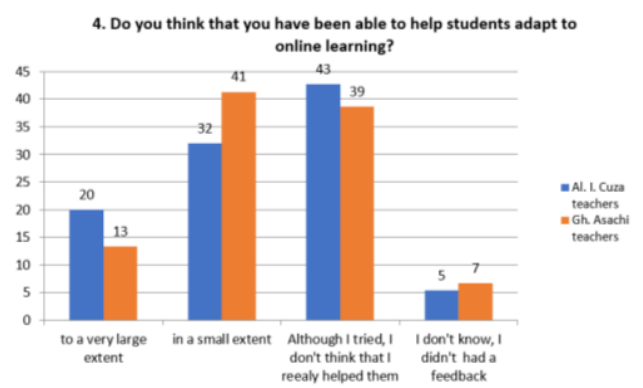

Figure 3. The structure of answers at question Q4

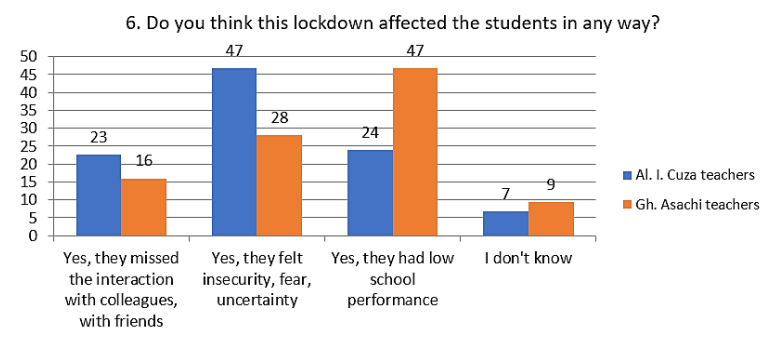

Figure 5. The structure of answers at question Q6

Figure 6. The structure of answers at question Q5 
7. What should be done to overcome the technical difficulties?

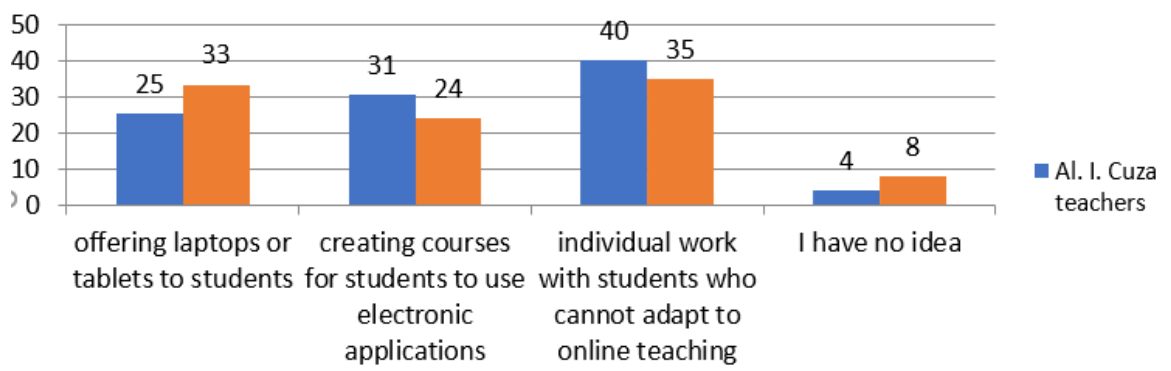

Figure 7. The structure of answers at question Q7

\section{What should be done to overcome the emotional problems?}

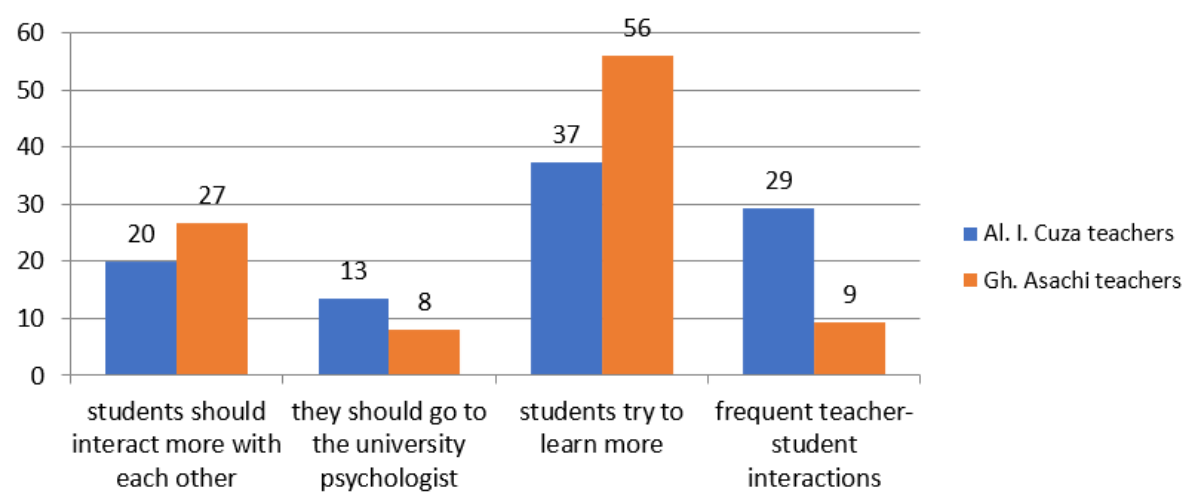

Figure 8. The structure of answers at question Q8

9. Would you agree to register your courses and post them on an online platform to facilitate student learning and more?

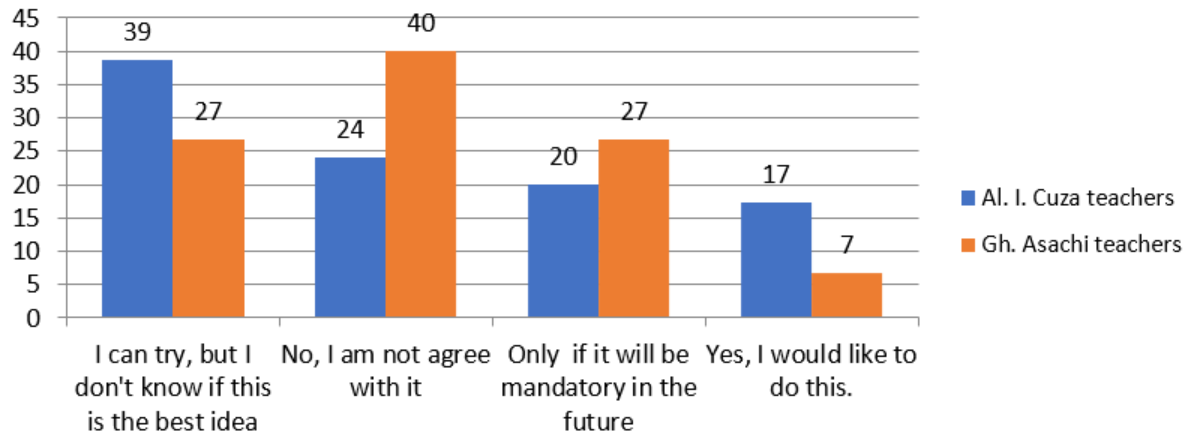

Figure 9. The structure of answers at question Q9 